Special Edition on Neuro-urology

\title{
Editorial special edition neuro-urology
}

(c) The Author(s), under exclusive licence to International Spinal Cord Society 2021

Spinal Cord (2021) 59:937-938; https://doi.org/10.1038/s41393021-00683-9

It was an honor and gratifying to coordinate this special edition on neuro-urology. The willingness to contribute of the experts in the field was a positive surprise and extraordinary during this worldwide crisis that affected and challenged us all. I appreciate the efforts of all who did and wanted to contribute and especially thank those, whose manuscripts got rejected during the review process. Furthermore, my thanks and appreciation go to the many reviewers who played a pivotal role in the making of this special edition.

Urologic complications are not the primary cause of death in individuals with spinal cord injury or disease (SCI/D) anymore [1]. However, neurogenic lower urinary tract dysfunction (NLUTD) and associated urologic complications are still among the most prevalent and severe health issues after SCI/D $[2,3]$. It is therefore no surprise that the restoration of bladder and bowel function is a top priority for individuals with SCI/D [4]. This is currently not (yet) possible and thus, our clinical and research efforts aim at the prevention, diagnosis, and treatment of associated complications such as upper urinary tract deterioration, urinary tract infections (UTIs), urolithiasis, and bladder tumors. At the same time, the effects of NLUTD and these measures on participation and quality of life of affected individuals need to be considered.

The diagnosis and treatment of UTIs continue to be a challenge in individuals with NLUTD. The real snag is the differentiation between a clinically relevant UTI that needs to be treated with antibiotics and bacteriuria that must not be treated. The evaluation of patient-reported symptoms potentially indicating a UTI is key for this differentiation in individuals with SCI/D [5]. Trachtenberg et al. [6, 7] evaluated the validity and reliability of two instruments for recording symptoms that are associated with UTIs in individuals using indwelling catheterization and those voiding (mostly) without a catheter. These standardized and validated instruments should be used universally to provide the data that will enable us to differentiate between UTI-related and unlikely UTI-related symptoms. In addition, urinary biomarkers are potentially valuable for identifying UTIs that require treatment. Forster et al. [8] observed higher levels of urine neutrophil gelatinaseassociated lipocalin in individuals likely to have a UTI compared to those with non-specific symptoms or less bacterial growth in the urine culture. Improving the specificity of identifying UTIs that require antimicrobial treatment will improve antibiotic stewardship. Furthermore, bacteriophages represent a very promising alternative and safe treatment for UTIs, especially in high-risk populations such as individuals with NLUTD [9].

Cancer is the third leading cause of death in individuals with $\mathrm{SCI} / \mathrm{D}$, and bladder cancer is the second most common cancer type in these individuals [10]. Böthig et al. [11] reported the characteristics of bladder cancer with regard to bladder management, type of bladder dysfunction, injury severity, and SCI/D duration in a cohort of 135 individuals with NLUTD.

Naturally, there are also psychosocial consequences of NLUTD and the management thereof. Vice-versa, health-related psychosocial aspects affect how individuals with NLUTD rate their bladder function and satisfaction. Furthermore, there is an interplay between bladder and bowel symptoms/management. In this edition, you find three articles that shed some light on these complex associations [12-14].

The attenuation of detrusor activity is currently the corner stone of protecting the upper urinary tract in individuals with neurogenic detrusor overactivity. However, catheters are required for bladder evacuation, and presently, there are no non-invasive, therapeutical options to elicit on-demand urination and defecation. Marson et al. investigated whether neurokinin 2 receptor agonists produce urination and defecation in a rat model of $\mathrm{SCl}$.

Further trials and studies with the aim to improve the situation of individuals affected by NLUTD are needed. Anderson et al. [15] showed how prospective cohort data can be used to assess trial feasibility regarding recruitment and operational requirements.

There are more interesting articles to discover in this special edition. I hope that you gain both knowledge and inspiration for further research.

\author{
Jörg Krebs (D) ${ }^{1 凶}$ \\ ${ }^{1}$ Clinical Trial Unit, Swiss Paraplegic Centre, Nottwil, Switzerland. \\ 凶email: joerg.krebs@paraplegie.ch
}

\section{REFERENCES}

1. Savic G, DeVivo MJ, Frankel HL, Jamous MA, Soni BM, Charlifue S. Causes of death after traumatic spinal cord injury-a 70-year British study. Spinal Cord. 2017;55:891-897.

2. Brinkhof MW, Al-Khodairy A, Eriks-Hoogland I, Fekete C, Hinrichs T, HundGeorgiadis $M$, et al. Health conditions in people with spinal cord injury: Contemporary evidence from a population-based community survey in Switzerland. J Rehabil Med. 2016:48:197-209.

3. Stillman MD, Barber J, Burns S, Williams S, Hoffman JM. Complications of Spinal Cord Injury Over the First Year After Discharge From Inpatient Rehabilitation. Arch Phys Med Rehabil. 2017;98:1800-1805.

4. Simpson LA, Eng JJ, Hsieh JT, Wolfe DL. The health and life priorities of individuals with spinal cord injury: a systematic review. J Neurotrauma. 2012;29:1548-1555.

5. Milligan J, Goetz LL, Kennelly MJ. A Primary Care Provider's Guide to Management of Neurogenic Lower Urinary Tract Dysfunction and Urinary Tract Infection After Spinal Cord Injury. Top Spinal Cord Inj Rehabil. 2020;26:108-115.

6. Tractenberg RE, Frost JK, Yumoto F, Rounds AK, Ljungberg IH, Groah SL. Reliability of the Urinary Symptom Questionnaires for people with neurogenic bladder (USQNB) who void or use indwelling catheters. Spinal Cord 2021. Online ahead of print.

7. Tractenberg RE, Frost JK, Yumoto F, Rounds AK, Ljungberg IH, Groah SL. Validity of the Urinary Symptom Questionnaires for people with neurogenic bladder 
(USQNB) who void or use indwelling catheters. Spinal Cord 2021. Online ahead of print.

8. Forster CS, Lamanna OK, Rounds A, Sprague BM, Ljungberg I, Groah SL. The association between urine neutrophil gelatinase-associated lipocalin and UTI in people with neurogenic lower urinary tract dysfunction. Spinal Cord 2020. Online ahead of print.

9. Leitner L, McCallin S, Kessler TM. Bacteriophages: what role may they play in life after spinal cord injury? Spinal Cord 2021. Online ahead of print.

10. National Spinal Cord Injury Statistical Center. 2020 Annual Statistical Report for the Spinal Cord Injury Model Systems. University of Alabama at Birmingham: Birmingham, Alabama. https://www.nscisc.uab.edu. Last access: June 2021.

11. Böthig R, Kowald B, Fiebag K, Balzer O, Tiburtius C, Thietje R et al. Bladder management, severity of injury and period of latency: a descriptive study on 135 patients with spinal cord injury and bladder cancer. Spinal Cord 2021: 1-7. Online ahead of print.

12. Welk B, Myers JB, Kennelly M, McKibbon M, Watson J, Gervais K. A qualitative assessment of psychosocial aspects that play a role in bladder management after spinal cord injury. Spinal Cord 2020. Online ahead of print.

13. Moghalu O, Stoffel JT, Elliott S, Welk B, Lenherr S, Herrick J et al. Psychosocial aspects of health-related quality of life and the association with patient-reported bladder symptoms and satisfaction after spinal cord injury. Spinal Cord 2021. Online ahead of print.
14. Stoffel JT, Barboglio-Romo P, Lenherr SM, Elliott SP, O'Dell D, Myers JB et al. Factors impacting bowel symptoms in a contemporary spinal cord injury cohort: results from the Neurogenic Bladder Research Group Registry. Spinal Cord 2021. Online ahead of print.

15. Anderson CE, Birkhäuser V, Stalder SA, Bachmann LM, Curt A, Jordan X et al. Optimizing clinical trial design using prospective cohort study data: a case study in neuro-urology. Spinal Cord 2020. Online ahead of print.

\section{COMPETING INTERESTS}

The author declares no competing interests.

\section{ADDITIONAL INFORMATION}

Correspondence and requests for materials should be addressed to J.K.

Reprints and permission information is available at http://www.nature.com/ reprints

Publisher's note Springer Nature remains neutral with regard to jurisdictional claims in published maps and institutional affiliations. 